\title{
Coreferential Devices in the Quranic Interpretation
}

\author{
Mohammad Muhassin'1, Dewi Ayu Hidayati² \\ ${ }^{1}$ Universitas Islam Negeri Raden Intan Lanpung, ${ }^{2}$ Universitas Lampung \\ mohammadmuhasin@radenintan.ac.id
}

\begin{abstract}
This article mainly discusses the coreference in the Quranic interpretation of Surah Albaqarah by Abdullah Yusuf Ali. The aims of the research are: to describe and explain the coreference types found in the Quranic interpretation, the coreference devices, and relationship types of the coreferential devices. The is a kind of descriptive qualitative research. The population consisted 286 interpretation texts of Surah Al-Baqarah with 112 samples taken as the data of the research chosen by using purposive sampling technique. The result of the research shows that the coreference types found in the Quranic interpretation are: repetition (6,55\%), lexical change (18,03\%), substitution (50,81\%) and ellipsis (24,59\%). Meanwhile, the coreferential devices found are: repetition, lexical change, and substitution. Finally, the relationship types of the co-referential devices are anaphoric $(88,52 \%)$ and cataphoric $(11,48 \%)$.
\end{abstract}

Key words: anaphoric and cataphoric relationship coreference, coreferential devices

\section{A. INTRODUCTION}

Brown says that language is more than a system of communication. Or we can say language is used as a tool of communication. In practical usage, language is not only seen as a tool of communication consisting of sounds, words, phrases, or sentences that stand alone separately, but also a series of sentences that are interrelated as well. The series of sentences connecting one proposition with others subsequently forms a unity called as discourse (Moeliono et al, 2008: 419).

A discourse also refers to the most complete unit of language in the form of written and spoken In addition, a coherent discourse can also be established 
through cohesion, the affinity relationship of propositions expressed by grammatical and semantic elements in sentences that form discourse (Halliday \& Hasan, 2005: 49; Muhassin, 2018). Take a look at the following dialog.

\section{A: What 's the matter with David?}

\section{$B: \underline{\text { He }}$ is rather sick.}

In example (1), utterance A is related to B because it is connected by the pronoun He referring to David. In this case, coreference occurs between noun David and pronoun $\mathrm{He}$ because both have the same referent. Thus the discourse (2) is said to be cohesive and coherent.

Coreference as an instrument of cohesion can be defined as words or phrases that express the bond of two or more things that refer to the same thing or referent (Saeed, 2009: 191). This can be interpreted that words or phrases having the same referent in a discourse are said to be the co-referential device of the discourse.

Some studies concerning coreference topics have been broadly discussed among the researchers. The topics concerned are Theory, Annotation, Resolution and Evaluation (Potau, 2010), On Paraphrase and Coreference (Recasens and Vila, 2010), Towards Multilingual Coreference Resolution (Zhekova, 2013), and Coreference Resolution for Russian: the Impact of Semantic Features (Toldova and Ionov, 2017).

The first part examines three separate but closely related aspects of the coreference resolution task, namely (i) the encoding of coreference relations in large electronic corpora, (ii) the development of learning-based coreference resolution systems, and (iii) the scoring and evaluation of coreference systems (Potau, 2010). Throughout this research, insight is gained into foundational problems in the coreference resolution task that pose obstacles to its feasibility. Hence, the main contribution resides in a critical but constructive analysis of 
various aspects of the coreference task that leads to rethink the concept of coreference itself.

In drawing the relation of paraphrase and coreference, Recasens and Vila (2010) suggest that paraphrase extraction and coreference resolution have applications in Question Answering, Information Extraction, Machine Translation, and so forth. Paraphrase pairs might be coreferential, and coreference relations are sometimes paraphrases. Paraphrasing concerns meaning, whereas coreference is about discourse referents. Thus, they do not always coincide.

The current work investigates the problems that occur when coreference resolution is considered as a multilingual task (Zhekova, 2013). The investigation carried out a detailed analysis that includes eight different languages (Arabic, Catalan, Chinese, Dutch, English, German, Italian and Spanish) for which datasets were provided by the only two multilingual shared tasks on coreference resolution held so far. The results confirmed that machine learning provides the needed flexibility for the multilingual task and that the minimal requirement for a language independent system is a part-of-speech annotation layer provided for each of the approached languages. It also showed that the performance of the system can be improved by introducing other layers of linguistic annotations, such as syntactic parses (in the form of either constituency or dependency parses), named entity information, and predicate argument structure.

Another report presents the result of experiments on building a general coreference resolution system for Russian (Toldova and Ionov, 2017). The main aim of those experiments was to set a baseline for this task for Russian using the standard set of features developed and tested for coreference resolution systems created for other languages. The research proposed several baseline systems, both rule-based and ML-based, and it showed that adding some semantic information was crucial for the task and even the small amount of data can improve the overall 
result. The result indicated that different types of semantic resources affected the performance differently and sometimes more did not imply better.

The discussion on the coreference in this research has a different point of view compared to the previous studies. It merely concerns on the pragmatic issue of the use of the coreferential devices in making a coherent discourse. Such device can be found in the English interpretation of the Quran as shown in the Surah Albaqarah.

2. This is the Book; in it is guidance sure, without doubt, to those who fear Allah.

(Ali, 1980).

In example (2), the unity of the discourse is represented by pronoun it that refers to noun the Book and both are co-referential because they refer to the same referent. The presence of co-referential devices makes the discourse coherent.

Teaching discourses for higher education students should be chiefly suggested. This is because of the lack of opportunity and teaching materials in the discourse study. For example, based on the researcher's experience, in teaching Introduction to Linguistics, he often finds students' difficulty to conduct a discourse analysis of English texts. This happened since the study of discourse had only a small portion of Introduction to Linguistics. In addition, the students got only few materials related to discourse analysis during the lectures.

As an effort to further enhance students' role in discourse analysis, the researcher is highly motivated to conduct the research on discourse analysis. This is to fulfill the students' need of discourse materials and their analysis. Therefore, the researcher is interested in investigating the application of discourse analysis in the English text in a study entitled Coreferential Devices in the Qur'anic Interpretation. 
In order to have a clear boundary, this study focuses on the description and explanation of coreference in the Quranic interpretation. Based on the background of the problem, the research questions can be formulated as follows.

1. What are the types of coreference in the Quranic interpretation?

2. What are the coreferential devices in the Quranic interpretation?

3. What are the relationship types of the coreferential devices in the Quranic interpretation?

\section{Reference and Coreference}

Reference in the view of the traditional semantics is the relationship between words and things. In line with this argument, Lyons (2006: 404) states that the relationship between the word with the object referred to as a reference. The word book for example has a reference to the object in the form of a set of paper bound to be written or read.

According to Halliday and Hassan (2005: 33), based on the direction, reference can be divided into two types, exophora and endophora. Exophora refers to things outside of text. Endophora refers to things indicated in the text and divided into two types.

Anaphora emphasizes on the precedents or previous items. Look at the sun. It's going down quickly. In this example, It refers to the sun.. Meanwhile Cataphora is a cross-reference to the antecedent or element afterwards. It 's going down quickly, the sun. In this example, the cataphoric word, It refers to the sun.

Based on previous discussion, it is noted that the reference is the relationship between language and the world outside language. Meanwhile, coreference is the relationship of language expressions in different parts of the text (Brown and Yule, 2003: 204). Thus, it can be stated that the relationship of coreference is just limited to the text concerned, or it is endophoric, either cataphoric or anaphoric. As the name implies, coreference means cross 
reference between two or more expressions that refer to the same referent. (Quirk et al, 1998: 863). This view limits the coreference's occurrence within the text, and also suggests the existence of cross-reference between elements that have the same reference, either anaphoric or cataphoric.

Based on direction, coreference can be anaphoric or cataphoric. Meanwhile its relationship can be distinguished on the shape of its elements interconnected (Brown and Yule, 2003: 193).

\section{B. RESEARCH METHOD}

In this paper, used descriptive qualtitative research. It is method which describe and interpret the object is accordance with reality.. This is a descriptive qualitative research in which it aims to describe the characteristics, properties, and images of the data accurately in accordance with the nature of the data themselves (Djadjasudarma, 2000: 15). In this case, the captured data really exist without considering whether the language used in discourse grammatical or ungrammatical. Moreover, qualitative study is naturalistic in which the data are stated in the forms of written or spoken words and people's behaviors that can be observed, not be changed in symbols and numbers (Sukidin \& Mundir, 2005: 23). In line with this argument, qualitative method emphasizes on an inductive data analysis, starting from the empirical facts on the ground which are then formed into the buildings of theory.

The population of this research is all texts of Quranic interpretation of Surah Albaqarah by Abdullah Yusuf Ali. The interpretation of Abdullah Yusuf Ali is selected because of its characteristics that stand out, i.e. very elegant style, the choice of words that is closer to the meaning of the original text, and the interpretation accompanied by notes and scientific reviews (Sherif, 1994: 232 ). Surat Al Baqarah is a surah with the most verses of the Quran . There are 286 verses in the texts of interpretation which have various kinds of coreference with 
its types. Meanwhile, the sample of the research was taken by using purposive sampling technique, that is, the selection of a group of subjects based on the criteria and research purposes (Sukidin \& Mundir, 2005: 63). Thus, this study obtained 122 data of the interpreted texts containing coreference cases between elements.

In analyzing the data, the researcher used a distributional method, namely by using the determined elements in the language studied (Djajasudarma, 1993: 60). The starting point began with the study of the data which had already been sorted through linguistic intuition. This study described the discourse into several elements, consisting of sentences, clauses, phrases and words containing coreferential elements.

The steps taken in analyzing the data were as follows:

1. Reading all the sentences and identifying each sentence by providing a number in parentheses at the beginning of the sentence;

2. Classifying data based on co-referential markers;

3. Categorizing and analyzing the data based on categories of words, phrases, clauses, and sentences which were co-referential;

4. Sorting and analyzing the data to determine the elements that were co-referential.

\section{FINDINGS AND DISCUSSIONS}

Coreference in the English interpretation of Surah Albaqarah is firstly characterized by types of coreference. One element of the sentence is co-referential with others when both refer to the same referent. Based on the data classification, there are four types of coreference, i.e (1) repetition, (2) lexical replacement, (3) substitution, and (4) deletion.

\section{Repetition}

Repetition mentions back an element of the sentence. It is intended to give emphasis on the content or massage delivered. The repetition is one of co- 
referential efforts to support the unity of the discourse. Repetition occurs eight times or $6.55 \%$. Consider the following example.

(1) 8. Of the people there are some who say: "We believe in Allah and the Last Day," but they do not (really) believe.

In (1), coreference is shown by the word believe in the construction ... We believe in Allah and is repeated back in ... but they do not (really) believe. Both are coreferential because in addition to having the same word class of verb, they also refer to the same referent, i.e. the meaning of 'trust / believe'.

The repetition of elements in the following discourse shows the same pattern.

(2) 15. Allah will throw their mockery back on them, and give them rope in their trespasses; so they will wander like blind ones.

(3) 37. Then learned Adam from his Lord words of inspiration, and his Lord turned toward him; for He is Oft-Returning, Most Merciful.

From the above data, it can be seen that the repetition is found in the word them (2), and his Lord (3). The repetition of them and his Lord makes the discourses co-referential because both refer to the same referent.

\section{Replacement}

Replacement is characterized by substituting sentence elements with others that are different but refer to the same referent. With the replacement, the discourse becomes coherent. There are 22 data containing replacement or $18.03 \%$. Consider the following examples.

(4) 9. Fain would they deceive Allah and those who believe, but they only deceive themselves and realize (it) not! 
In (4), replacement is seen by substituting pronoun they with a different form of pronoun, i.e themselves. Both are co-referential because they and themselves refer to the same referent. The same pattern is found in the following discourse.

(5) 10. In their hearts is a disease; and Allah has ncreased their disease, and Grievous is the penalty they (incur), Because they are false (to Themselves).

(6) 13. When it is said to them: "Believe as the others believe" they say: "Shall we believe as the fools believe?" nay, of a surety they are the fools but they do not know.

From the above data, it is found that the replacement occurs by substituting a disease with their disease in (5) and they with we in (6). Both are co-referential because of having the same referents.

\section{Substitution}

Substitution is characterized by the replacement of the elements of sentences with pronouns that have the same referents. It is found as many as 62 data of substitution or $50.81 \%$. Consider the following examples.

(7) 2. This is the Book; in it is guidance sure, without doubt, to those who fear Allah.

In (7) substitution occurs as the noun the Book is replaced by pronoun it that refer to the same thing. Substitution can also be seen in the following data.

(8) 21. O ye people! adore your Guardian-Lord, who created you and Reviews those who Came before you, that ye may Become righteous.

(9) 30. Behold, thy Lord said to the angels: "I will create a vicegerent on earth." They said, "Wilt thou place Therein one who will Therein the make mischief and shed blood? Whilst we do celebrate Thy Praises and Glorify Thy holy ( name)?" He said: "I know what ye know not." 
From the above data, substitution occurs with replacing the word people with you (8) and the angels with they (9). Both are respectively co-referential because of having the same referents.

\section{Deletion}

Deletion or ellipsis is a relationship marker between elements in sentences. it is characterized by sentence elements that are not stated explicitly but its presence can be foreseen. Based on data classification, deletion is marked by disappearances of sentence's functions, such as subject $(\mathrm{S})$, Predicate $(\mathrm{P}), \mathrm{O}$ (Object), Adv (Adverb), and Com. (Complement). With the deletion, the relationship between elements of sentences is closely tight, that is by avoiding the use of the same words monotonously. It is noted that there are 30 data containing deletion or $24.59 \%$. Consider the following examples.

(10) 211. Ask the Children of Israel how many clear signs We have sent them. But if anyone, after Allah's favor has come to him, substitutes (something else), Allah is strict in punishment.

In (10) deletion occurs on a phrase something else that serves as $\mathrm{O}$ of verb substitutes. The presence of these phrases can be predicted with filling in parentheses. The phrase has the same referent with the phrase God's favor so that both are co-referential.

The following discourse shows the same pattern.

(11) 143. Thus Spake have We made of you an Ummah justly balanced, that ye might be witnesses over the nations, and the Messenger a witness over yourselves; and We appointed the Qiblah to the which thou wast used, only to test those who Followed the Messenger from those who would turn on their heels (from the faith). Indeed it was(a change) momentous, except to those guided by Allah. And never would Allah Make your faith of no 
effect. For Allah is to all people most surely full of kindness, Most Merciful.

(12) 19. Or (another Similitude) is that of a rain-laden cloud from the sky; in it are zones of darkness, and thunder and lightning, they press their fingers in their ears to keep out the stunning thunder-clap, the while they are in terror of death. But Allah is ever round the rejecters of Faith!

In the two above discourses, deletion is characterized by the removal of the elements of a sentence, that is another similitude as Subject in (11) and $a$ change as Complement (12). Nevertheless, the presence of elements which was removed can be foreseen with the filling in parentheses.

\section{Coreferential Devices in the Quranic Interpretation}

Coreferential devices refer to elements of sentences which signal the coreference due to the same referents. Based on data classification, there are fourteen co-referential devices found in the Quran, i.e. repetitions of (1) words, (2) phrases, replacements of (3) word by word, (4) word by phrase, (5) phrase by word, (6) phrase by phrase, (7) clause by word, substitutions (8) of I by Me, (9) by They, Them, Themselves, (10) by He and Him, (11) by We, (12) by It, (13) by This, That, Those, and (14) by You.

\section{Repetition of words}

Repetition of words occurs when a word as a discourse element is repeatedly mentioned to show the same meaning.

(13) 9. Fain would they deceive Allah and those who believe, but they only deceive Themselves and realize (it) not!

In (13), the element repeated, the verb deceive is co-referential since both have the same referent of meaning.

The same pattern occurs in the following discourse.

(14) 74. Thenceforth were your hearts hardened; they Became like a rock and even worse in hardness. For Among rocks there are some 
from the which rivers gush forth; others there are the which when split asunder send forth water; and others roommates sink for fear

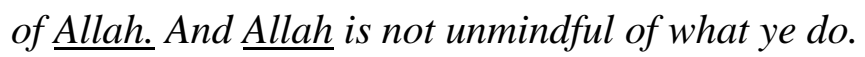

(15) 152. Then do ye remember Me; I will remember you. Be grateful to Me, and reject not faith.

Repetition of words can be signaled by re-mentioning the word Allah in (14) and pronoun $M e$ in (15). The repetition shows the coreference due to the same referent.

\section{Repetition of phrases}

In this type, a discourse element, a phrase is wholly restated as can be seen in the following examples.

(16) 37. Then learned Adam from his Lord words of inspiration, and his

Lord turned toward him; for He is Oft-Returning, Most Merciful.

(17) 59. But the transgressors changed the word from that the which had been given them; so We sent on the transgressors a plague from heaven, for that they infringed (our command) repeatedly.

The repetition is signaled by the restatement of the phrase his Lord in (16) and the transgressors in (17). The phrase repetition shows the coreference due to the same meaning both have respectively.

\section{Replacement of word by word}

This replacement occurs when a word as a discourse element is replaced by a different word but with the same referent.

(18) 13. When it is said to them: "Believe as the others believe" they say: "Shall we believe as the fools believe?" nay, of a surety they are the fools but they do not know.

(19) 14. When they meet those who believe, they say: "We believe," but when they are alone with their evil ones, they say: "We are really with you, we (were) only jesting." 
English Education: Jurnal Tadris Bahasa Inggris, Vol. 12 (1), 2019..., pISSN 2086-6003 | eISSN 2580-1449

(20) 85. After this it is ye, the same people, who slay Among yourselves, and banish a party of you from their homes; assist (their enemies) against them, in guilt and rancor; and if they come to you as Captives, ye ransom them, though it was not lawful for you to banish them. Then is it only a part of the Book that ye believe in, and do ye reject the rest? But what is the reward for you Among Reviews those who behave like this but disgrace in this life? and on the Day of Judgment they shall be consigned to the most Grievous penalty. For Allah is not unmindful of what ye do.

In the three discourses above, word to word replacement occurs as a word is substituted with different words, but with the same referent. Here pronoun them is replaced by we in (18), they by we in (19) and a noun it by the book in (20).

\section{Replacement of word by phrase}

Replacement of word to phrase occurs when a word is replaced by a higher level element, namely a phrase that has the same referent.

(21) 16. These are they who have bartered guidance for error: but their traffic is profitless, and they have lost true direction.

(22) 26. Allah disdains not to use the Similitude of things, cancel as well as highest. Those who believe know that it is truth from their Lord; but those who reject Faith say: "What means Allah by this Similitude?" By it He causes many to stray, and many He leads into the right path, but He causes not to stray, except Reviews those who forsake (the path).

(23) 62. Those who believe (in the Qur'an) and Reviews those who follow the Jewish (Scriptures), and the Christians and the Sabians, and who believe in Allah and the last day, and work righteousness, 
shall have their reward with their Lord; on them shall be no fear, nor shall they grieve.

The replacement of word to phrase is signaled by substituting a word by a phrase that has the same referent. Here the word guidance is substituted by the phrase true direction in (21), Allah by their Lord in (22), and (23). This replacement is coreferential due to the same referent they have respectively.

\section{Replacement of phrase by word}

In this type of replacement, a phrase is substituted by a lower level, namely a word as can be seen on the examples below.

(24) 35. We said:

"O Adam! Dwell thou and thy wife in the Garden, and eat of the bountiful things Therein as (where and when) ye will, but approach not this tree, or ye run into harm and transgression."

(25) 58. And remember We said:"Enter this town, and eat of the plenty Therein as ye wish; but enter the gate with humility, in posture and in words, and We shall forgive you your faults and increase of (the portion of) those who do good."

(26) 74. Thenceforth were your hearts hardened; Became they like rock and even worse in hardness. For Among rocks there are some from the which rivers gush forth; others there are the which when split asunder send forth water; and others roommates sink for fear of Allah. And Allah is not unmindful of what ye do.

The replacement occurs when the phrase the garden is substituted by the word Therein in (24), the phrase this town by the word Therein in (25) and the phrases your hearts with the word rock in (26). The replacement is co-referential due to the same referents they have respectively. 
English Education: Jurnal Tadris Bahasa Inggris, Vol. 12 (1), 2019..., pISSN 2086-6003 | eISSN 2580-1449

\section{Replacement of phrase by phrase}

In this type of replacement, a phrase is substituted by a different phrase, but with the same referent. Take a look at the following data.

(27) 36. Then did Satan of the make them slip from the (garden), and get them out of the state (of felicity) in the which they had been. We said: "Get ye down, all (ye people), with enmity between yourselves. On earth will be your dwelling place and your means of livelihood for a time. "

(28) 69. They said: "Beseech on our behalf thy Lord to the the make plain to us her color." He said: "He says, a fawn-colored heifer, pure and rich in tone, the Admiration of beholders!"

(29) 177. It is not righteousness that ye turn your faces toward the East or West; but it is righteousness to believe in Allah and the Last Day, and the Angels, and the Book, and the Messengers; to spend of your substance, out of love for Him, for your kin, for orphans, for the needy, for the wayfarer, for those who ask, and for the ransom of slaves; to Be Steadfast in prayer, and practice regular charity; to fulfill the contracts the which ye have made; and to be firm and patient, in pain (or Suffering) and adversity, and throughout all periods of panic. Such are the people of truth, the God-fearing .

The replacement occurs when the phrase on earth is substituted by the phrase your dwelling place in (27), the phrase her color by the phrase a fawncolored heifer in (28) and the phrase the people of truth by the phrase the Godfearing in (29). The replacements are co-referential since they have the same referent respectively. 


\section{Replacement of clause by word}

In this type of replacement, a clause as a discourse element is substituted by a lower level element, namely a word as can be seen on the following example.

(30) 22. Who has made the earth your couch, and the heaven your canopy; and sent down rain from the heavens; and brought forth therewith fruits for your sustenance; then set not up rivals unto Allah when ye know (the truth).

In (30), the replacement is characterized by substituting the clause Who has made the earth your couch with the word Allah that has the same referent. Therefore, both are co-referential.

\section{Substitution of I by Me}

This type of substitution is characterized by the replacement of pronoun $I$ by pronoun me. Give a notice to the following example.

(31) 41. And believe in what I reveal, confirming the revelation which is with you, and be not the first to reject faith Therein, nor sell My Signs for a small price: and fear $\underline{\mathrm{Me}}$, and Me alone.

The substitution occurs when pronoun $I$ is substituted by pronoun me. Both are coreferential due to the same referent they have.

\section{Substitution by they, them, themselves}

This substitution is characterized by replacing elements of the discourse with pronouns they, them, themselves as illustrated by the bottom line.

(32) 155. Who believe in the Unseen, are Steadfast in prayer, and spend out of what We have Provided for them.

(33) 67. As to review those who reject Faith, it is the same to them Whether thou warn them or do not warn them; they will not believe.

(34) 174. Those who conceal God's Revelations in the Book, and purchase for them a miserable profit, they swallow into 
Themselves naught but Fire; Allah will not address them on the Day of Resurrection, nor purify them; Grievous their penalty will be.

The substitution is signaled by replacing Who believe in the Unseen with them in (32), those who reject Faith with they in (33), and Those who conceal God's Revelations in the Book with Themselves in (34). The replacements make the discourses co-referential due to the same referents the elements have respectively.

\section{Substitution by He and Him}

This type of substitution is characterized by the replacement of the element of the sentence by the pronouns He and Him as shown on the following examples.

(35) 20. The lightning all but snatches away their sight; every time the light (helps) them, they walk Therein, and when the darkness grows

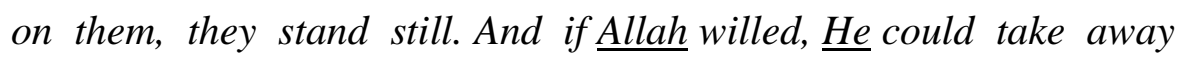
their faculty of hearing and seeing; for Allah hath power over all things.

(36) 28. How can ye reject the faith in Allah? Seeing that ye were without life, and He Gave you life; then will He cause you to die, and will again bring you to life; and again to $\underline{\mathrm{Him}}$ will ye return.

(37) 137. So if they believe as ye believe, they are indeed on the right path; but if they turn back, it is they who are in Schism; but Allah will suffice thee as against them, and $\underline{\mathrm{He}}$ is the AllHearing, the All-Knowing.

The substitution is signaled by replacing Allah with $\mathrm{He}$ in (35), with Him in (36), and with $\mathrm{He}$ in (37). The replacement make the discourses co-referential due to the same referents the elements have respectively.

\section{Substitution by We}

This type of substitution is characterized by the replacement of the elements of the discourse by pronoun We as illustrated below. 
English Education: Jurnal Tadris Bahasa Inggris, Vol. 12 (1), 2019..., pISSN 2086-6003 | eISSN 2580-1449

(38) 66. So We made it an example to their own time, and to reviews their posterity, and a lesson to review those who fear Allah.

(39) 73. So We said: "Strike the (body) with a piece of the (heifer)." Thus Spake Allah bringeth the dead to life and showeth you His Signs, perchance ye may understand.

(40) 143. Thus Spake have We made of you an Ummah justly balanced, that ye might be witnesses over the nations, and the Messenger a witness over yourselves; and We appointed the Qiblah to the the which thou wast used, only to test those who Followed the Messenger from those who would turn on their heels (from the faith). Indeed it was (a change) momentous, except to those guided by Allah. And never would Allah Make your faith of no effect. For Allah is to all people most surely full of kindness, Most Merciful.

The substitution is identified by replacing Allah with We in (38-40). The replacements make the discourses co-referential due to the same referents the elements have respectively.

\section{Substitution by It}

This substitution is characterized by the replacement of the elements of the discourse by pronoun It as shown on the following examples.

(41) 12. Of a surety, they are the ones who make mischief, but they realize it not.

(42) 17. Their Similitude is that of a man who kindled a fire; when it lighted all around him, Allah took away their light and left them in utter darkness, so they could not see.

(43) 19. Or (another Similitude) is that of a rain-laden cloud from the sky; in it are zones of darkness, and thunder and lightning, they press their fingers in their ears to keep out the stunning thunder-

English Education: Jurnal Tadris Bahasa Inggris, Vol. 12 (1), 2019, 114 
clap, the while they are in terror of death. But Allah is ever round the rejecters of Faith!

The substitution is signaled by replacing mischief with It in (41), a fire with it in (42), and a rain-laden cloud with it in (43). The replacements make the discourses co-referential due to the same referents the elements have respectively.

\section{Substitution by This, That and Those}

This substitution is characterized by the replacement of the elements of the discourse by the demonstrative pronouns this and that.

(44) 79. Then Woe to those who write the Book with their own hands and then say: " This is from Allah," to traffic with it for a miserable price! Woe to them for what their hands do write, and for the gain they make thereby.

(45) 215. They ask thee what they should spend (in charity). Say: Whatever ye spend that is good, is for parents and Kindred and orphans and those in want and for Wayfarers. And whatever ye do that, Allah knoweth it well.

The substitution is signaled by replacing the Book with this in (44), and Whatever ye spend that is good with that in (45). The replacements make the discourses coreferential due to the same referents the elements have respectively.

\section{Substitution by You}

This substitution is characterized by the replacement of the elements of the discourse by pronoun You. Give notice to the following example.

(46) 40. O children of Israel ! Call to mind the (special) favor which I bestowed upon you, and fulfill your covenant with Me as I fulfill My covenant with you and fear none but Me. 
The substitution is signaled by replacing $O$ children of Israel with you in (46). The replacement makes the discourse co-referential due to the same referent the element has.

\section{Relationship types of coreferential devices}

Anaphoric relationship is the relationship between elements referring to antecedents. The latter element has the same referent as the previous one. Data containing anaphoric relationship are 108 of 122 or $88.52 \%$. Here are the examples of anaphoric relationship in the Quran.

(47) 17. Their Similitude is that of a man who kindled a fire; when it lighted all around him, Allah took away review their light and left them in utter darkness, so they could not see.

(48) 33. He said: "O Adam! Tell Them their natures." When he had of tell them, Allah said:

"Did I not tell you that I know the secrets of heaven and earth, and I know what ye reveal and what ye conceal?"

(49) 198. It is no crime in you if ye seek of the bounty of your Lord (during Pilgrimage). Then when ye pour down from (Mount) Arafat, celebrate the Praises of Allah at the Sacred Monument, and celebrate His Praises as He has directed you, even though, before this, ye went astray.

From the above data, it is known that the anaphoric relationship occurs as pronoun It refers to a fire in (47), he to Adam in (48) and He to Allah in (49).

\section{Cataphoric relationship}

Cataphoric relationship is the relationship between elements in the discourse referring to the antecedent. The prior element has the same referent as the latter element. There are 14 data containing cataphoric relationship of 122 research data or $11.47 \%$. Here are the examples. 
English Education: Jurnal Tadris Bahasa Inggris, Vol. 12 (1), 2019..., pISSN 2086-6003 | eISSN 2580-1449

(50) 5. They are on (true) guidance, from their Lord, and it is these who will prosper.

(51) 23. And if ye are in doubt as to what We have revealed from time to time to Our servant, then produce a Sura like thereunto; and call your Witnesses or helpers (if there are any) besides Allah, if your (doubts) are true.

(52) 137. So if they believe as ye believe, they are indeed on the right path; but if they turn back, it is they who are in Schism; but Allah will suffice thee as against them, and He is the All-Hearing, the AllKnowing.

From the above data, it is known that the cataphoric relationship is indicated by the use of pronoun they referring to These who will prosper in (50), We to Allah in (51) and He to the All-Hearing, the All-Knowing in (52).

\section{CONCLUSIONS AND SUGGESTION}

Based on data analysis, the researcher can make conclusions as follows.

1. Coreference types in the Quranic interpretation include repetition, replacement, substitution and deletion. Substitution places the highest rank of occurrence with 62 data (50.81\%), then consecutively deletion with 30 data $(24.59 \%)$, the replacement with $22(18.03 \%)$, and the repetition with 8 data $(6.55 \%)$.

2. Co-referential devices found in the Quranic interpretation are: repetition of words, phrases; replacement of word by word, phrase by phrase, word by phrase, phrase by word, and clauses by word. Substitution is marked with pronouns $I t$, Them, they, we, he, you, him, I, me, we, her, thou, you, ye, this, that and those.

3. The relationship types of co-referential devices in the Quran are anaphoric and cataphoric. There are 108 of 122 research data or $88.52 \%$ categorized as anaphoric

Meanwhile the rest of the data, four of 122 data or $11,47 \%$ categorized as cataphoric.

English Education: Jurnal Tadris Bahasa Inggris, Vol. 12 (1), 2019, 117 
Things that need to be studied further in the future studies, especially related to the English interpretation of Quran are focusing on word class coreference, displacement of word class in lexical replacement, and syntactic function of the elements which are coreferential.

\section{E. REFERENCES}

Ali, Abdullah Yusuf. (1980). The Holy Qur'an: Text, Translations and Commentary. Lahore: Ashraf Printing Press.

Cook, Gay. (2007). Discourse. London: Oxford University Press.

Brown, Gillian and Yule, George. (2003). Discourse Analysis. New York: Cambridge University Press.

Djajasudarma, T.F. (2000). Metode Linguistik: Ancangan Metode Penelitian dan Kajian. Bandung: Eresco.

Givon, Talmy. (2000). Definiteness and Referentiality. In J. H. Greenbergs (ed). Universals of Language. Standford: Standford UP.

Halliday, M.A.K \& Hassan, R. (2005). Language, Context and Text. Victoria: Deakin University

Kridalaksana, H. (2011). Kelas Kata dalam Bahasa Indonesia. Jakarta: PT Gramedia.

Lyons, John. (2006). Semantics 2. Cambridge: Cambridge University Press.

Moeliono, A. et al. (2008). Tata Bahasa Baku Indonesia. Jakarta: Depdikbud.

Muhassin, M. (2018). Cohesive Markers Found in Thesis Abstracts. English Education: Jurnal Tadris Bahasa Inggris, 11(1), 118-132. Retrieved from http://ejournal.radenintan.ac.id/index.php/ENGEDU/article/view/2672

Potau, M.R. (2010). Coreference: Theory, Annotation, Resolution, and Evaluation. Unpublished Dissertation. Ph.D Program. University of Barcelona. 
Recasens, M. and Vila, Marta. (2010). On Paraphrase and Coreference. Computational Linguistics Vol. 36 No. 4. Retrieved February 2, 2018 from http.//mitpressjournals.org/doi/pdfplus/10.1162/coli_a_00014.

Toldova, S. and Ionov, M. (2017). Coreference Solution for Russian: The Impact of Semantic Features. Proceeding of International Conference Dialogue. May 31-June 3, 2017. Russian Foundation for Basic Research Fund.

Quirk, R. et al. (1998). A Comprehensive Grammar of the English Language. London: Longman.

Saeed, J.H. (2009). Semantics. Massachusetts: Blackwell Publishers.

Sherif, M.A. (1994). Searching the Solace: A Biography of Abdullah Yusuf Ali, Interpreter of the Qur'an. Kuala Lumpur: Book Center Trust.

Tarigan, H.G. (2006). Pengajaran Wacana. Bandung: Angkasa.

Sukidin dan Mundir. (2005). Metode Penelitian. Jakarta: Insan Cendekia.

Zekhova, D. (2013). Toward Multilingual Coreference Resolution. Unpublished Dissertation. Ph.D Program. University of Bremen. 